\title{
Colonization and Cultural Values of Yorùbá People: A Case of Traditional Drums in Yorùbá Land
}

\author{
Aladesami Ọmọ́bọ́lá Agnes \\ bolaaladesanmi@gmail.com \\ Department of Linguistics and Nigerian Languages, Ekiti State University
}

\begin{abstract}
Culture is one of the marks by which a community of people of a nation is normally identified. Culture is a phenomenon that distinguishes one ethnic tribe from the other. Various cultures can be identified among the people that are found in a particular community setting. Some cultures can be similar among different people but cultures that differ one from the other are peculiar to people of various tribes. Culture and tradition are sometimes used interchangeably. However, these two concepts have some differences. Tradition is rooted in religious beliefs of a people while culture is embedded in the social activities and social values of a people. Culture is multi-dimensional. Among the Yorùbá ethnic group of South Western Nigeria, there are different cultures that can be identified. Some of these cultures include but not limited to: tribal marks, mode of greetings, dressing/hairstyle and music in which drums are embedded. The focus of this paper is on the use of traditional drums among the Yorùbá. The paper shall examine the origin of drum beating, types of drums and the type of drum beating that is peculiar to each activity and the phenomenon of drum beating in the past and now. The paper discusses the influence the modern technological development has brought into the issue of traditional drums both in positive and negative ways. The paper concludes that this culture is gradually fading away among the Yorùbá people and observed that this is due to the fact that not much value is placed on Yorùbá culture anymore and this is very inimical to the sociocultural belief of the people.
\end{abstract}

Keywords: culture, traditional Drums, technology, socio-cultural belief

\section{Introduction}

Yorùbá people are highly noted for their reference for their gods. Religion is a major part of Yorùbá culture; it is through this culture that they showcase their respect for their religious beliefs. They give the best instruments and materials in the worship of their gods. One of the most important instruments used in the worship of their god is the drum. Drums are vital parts of the cultural heritage of the Yorùbá especially the attendant impact on the generational transfer of this heritage territorially.

According to Merriam Webster (1995), drum can be defined as a musical object made up of a hollow-shell or cylinder with a drumhead which can be made up of hard skin stretched over on or both ends and it can be beaten with hands or stick or wire brush. Corroborating the above, Wikipedia also maintains that in Hornbostel Sachs classification system, drum is categorized as one of the percussion group of musical instruments. Most 
drums are made of animal skins and wood. Drums are the basic instruments for most Yorùbá music. The act of playing this musical instrument to produce melodious rhythms and tone is called drumming. Traditionally, in Yorùbá culture, drumming acts as a musical bridge between humans and different deities.

Deity is called "òrìsà̀" in Yorùbáland. It provides guidance and intervention in their daily lives. Drumming provides a link between the supernatural world and the physical world by acting as a communicative agent that calls down the deity in order to provide assistance and guidance to the worshippers. Each deity has a drum attached to him or her. The type of drum used for communication and entertainment varies from one community to another. The Yorùbá do not only use their drums for entertainment alone, they use it as a means of communication, praise-sing, announcing declaration of hostility, war, mourning and sober reflections. When the Yorùbá hear a certain sound of drum beat, even without getting to the place or places where the sound is emanating from, the sound of the drum would have communicated to the hearers, the message the drum beat is conveying.

In Yorùbáland, drumming styles differ from one period to the other. For examples, drums are used to announce the emergence of Egúngún (masquerades), for social events, for hunters going on hunting expeditions and also drums are used for sober reflection during mourning and also during war. The drumbeat during war sounds hard. For example, "olọmọ kilọ f'ọ́mọ rẹ, òní a ro". The meaning of this song is summarized in this phrase: "warn your wards, today would be tough". And for death (dirge) songs; a good example is the one that goes thus:

\section{"yépà motirodo lọ pọnmi, yépà motirọsà lo fọso, ìgbì modélé mi ò bẹnikan ojú mi ń șomigbéré".}

Alas, I went to the sea to fetch water, And to the river to wash clothes On getting home, my loved ones are no more,

\section{Tears roll down my cheeks uncontrollably.}

Drums are inseparable from Yorùbá culture. It is a vital part of Yorùbá culture that helps define and give rich values to the culture. On special occasions like carnivals, ceremonies, and festivals, drums are being used. The occasion dictates in Yorùbáland the kind of drum to be beaten. They add special effects and styles to culture. Drum beats are beauty to the ears. When a praise singer sings and a gifted hand handles the sticks to a drum, the ears of the listener ticks and his or her head swells: wounds are healed and spirits are lifted.

In the history of Africans, particularly among Yorùbá people of South Western Nigeria, traditional drums maintain a special place. The concept of drumming is practically associated with entertainment in a bit to add to the musical quality of a song in the Western Culture. A deeper symbolic and historical meaning is being attached to drums in Africa, especially in Yorùbáland for any manner of ceremony. In other traditional festivals, drums are always included and play major roles. The aggressive sounds of many drums are being used to inspire excitement and passion, also to stirrup emotions in a battle or war. Some particular drums emblematize and guard royalty and are often kept in holy abode. A good example of this among the Yorùbá is the one called "Gbedu" (Arowolo, 2010). Arowolo (2010) sees culture as an entirety of a set of values and norms, belief system; bequeathed idea which makes up the common bases of generally agreed social action.

For a viable and healthy society, culture is very germane. Culture can be seen as a custom, tradition practices and behaviour of a specific nation and its people. The history of colonization can be traced back to the $19^{\text {th }}$ century, when Africa as a continent and Nigeria as a country could not exercise their sovereignty back then. For Nigeria, the experience of colonization was a sweet and bitter taste in a man's mouth just like a Yorùbá adage that says “o busósíni lẹnu; ó túnbuyọ si; iyọ̀ ò șe é tudànù, bẹệniisó ò șe é pọnlá". Even after Independence in 1960, Nigeria only gained independence 
physically, but still mentally enslaved to the Europeans. The colonialist and explorers who exploited Africa and Nigeria in particular robbed us of our beautiful culture.

According to Concise Oxford Dictionary of Politics, colonialism is the policy and practice of a strong power extending its control territorially over a weaker nation or people. It came from a Latin word "Colonia" which simply means a Country Estate. As a thought, Colonialism more often as an attribute of the nineteenth century imperialist who obtained huge tracts of the Universe to find derogatory to denote an unwanted sense of attitudes, beliefs, practices, and racial superiority that sprang from this sense. Colonization brought about modernization, globalization, and technology. With the raise of in streaming modernization, technology and globalization, our hallowed and most cherished culture is losing its strength, value awesomeness and dignity.

Hofstede (1997), claims that culture delegate a cumulative deposit of belief, values, knowledge, experience, attitudes, religion, meanings, hierarchies, notion of time, spatial relations, roles, concept of the universe through individual and group striving acquires from the universe, material objects and possessions. Adépéjú Oti and Oyèbọ́lá Ayẹni (2013) mention that civilization has brought about an undesirable effect on Yorùbá cultural values and the language, making it an endangering specie, a culture that is fast losing space among elitist homes, public, and private institutions.

Ọládoṣù Olúșégun (2015) posits that it is from trees that behave in humans ways that drums are made of, the trees are recognized to have abhorred different supernatural beings which Yorùbá people reverence with "ìpèsè" or "ebo" (offering). He explains further that it is the belief of Yorùbá about drums that harbours spiritual habits that they are formed from and these make their use important in the Yorùbá community within the religious practise in which they connote. Japhet Alakam in his article "Excellence in Style: The Uniqueness of Yorùbá drums" in Vanguard of February (2017) states that before modern civilization infiltrated the culture of many tribes and ethnic communities, the Yorùbá people of south western Nigeria have fashioned out the way to entertain themselves during traditional festival, chieftaincy coronation, naming ceremonies and all sort of events." Bádé Àjàyí (1992) examines the place of the Yorùbá talking drum in social mobilization. He presents the Yorùbá talking drum as a powerful means of exciting and motivating listeners to achieve specific goals. He also demonstrates how the drummer in his capacity as a mass communicator uses his instrument to mobilize members of the community either positively or negatively.

Charles A. Ellwood, an American Sociologist (Cited in Amponsah, 2010, p. 597) reveals the multifaceted nature of culture when he encapsulated to convey; a collective name for all behaviour patterns socially gained and socially transmitted by means of symbols; hence a name that distinguishes achievement of human sets, not only including such items as language, tool making, art industry, religion, morals, science, law, government and morals, also the material instruments or artefacts in which cultural achievements are included and by which intellectual cultural attributes are given practical result, such as art objects, machines, tools, communication devices, buildings, etc. The crucial part of culture could be found in the cycles embodied in the social traditional groups; that is, in knowledge, value, ideas, beliefs, standards and sentiments and rife. The open part of culture is to be found in the real behaviour of the group, mainly in its usage, customs and institution. The crucial part of culture seems to be values with reference to life conditions been appreciated. The purely behavioural meaning of culture is, therefore inadequate. The accomplished definition must involve the subjective and objective appearance of culture. Practically, traditions and customs are summed up in the culture of a human group; but tradition, is essential as a subjective side of culture. (Cited in Amponsah, 2010,p. 597)

Bankole (et. al.) noted that among Yorùbá people, İrókò tree is not really peculiar to the 
making of drums. Trees like "igi òmọ̆" and "ọpá" owing to their good tone value are the most enumerated when it comes to drum making. However, the spiritual beings in tress are seen as itinerant forces that have their liberty and without a special sacrifice or libations can be cut down. He went further to say that the understanding in the belief linked with the drums posed some effects on their maintenance and treatment.

\section{Relationship between Colonization and Culture}

Kasongo (2010) was of the opinion that one could assume that when Westernisation was brought into African countries, the secret side of modernisation was materialist concerned. Another concept of domination is civilisation: infliction of incoming culture over traditional ethic. Similarly Igboin (2011) is of the opinion that the traditional machinery of moral homogeneity and practice was disrupted by the colonial rule. The process of moral inculcation was damaged, which resulted in the nonchalance of traditional norms and values through a systematic depersonalisation of the African and paganisation of its quality. Instead of the treasured communalism which defined the life of the African, an expending societal construct was made known, which isolate and destroys the organic fabric of the spirit of wefeeling. Moreso, Falana (2018) said that it is a known fact that cultural change in Africa is majorly informed by colonialism.

\section{The Place of Drums in Culture}

Drums are found in nearly every culture of the world and have existed since before 6000BC. They have ceremonial, sacred and symbolic association. Drums are intrinsic part of African culture; it is an important component of culture which cannot be separated from. According to Bankole, in traditional way, drums are meant to be hung, set in the sun when it is not in use, or placed in a reserved place. This gives a relatively arid and an agitated storing place. He also notes that the drum must not be handled carelessly in such a way that can be dropped, thrown, stepped over, sat on or used to curse someone. If this happens intentionally or not, it becomes a serious matter or a sage sin that must be expiated. It is a serious sin as a social custom to Ayàn, the god of the drum. In case the drum is broken, it is being buried like a human being in a special ceremony wrapped in a white cloth. This is an indication to the fact that the weight of the outcome is great and the spirit of the gods needed to be appeased, if the spirit of the drum is not appeased, a proper scarifies restitution must be made for the person who broke the drum, else the person will have no rest.

\section{History of Drums}

Tọ́lá Adénlé (2014), in one of his articles, mentions some drummers in recent times who play or carry out their acts of drumming with high dexterity. These include drummers, of late Àtáojà, Adénlé I, late Shittu Okánjúà. Others are Babátúndé Ọlátúnjí (1927-2003) and one of the drummers a royal father, Late Ọba Láoyè, the Timì of Edẹ land. Ọba Láoyè through his dexterity in drumming with the dùndún produced signature tune for the Western Nigeria Broadcasting Station. However, this is the first Nigeria Broadcasting Service". Some who may not know the meaning of the tones misinterpreted Tìmì to mean "kò sónígbèsè nibi, e lo sílé keji" (There is no debtor here, go to the next house) or "BÓlúbàdàn ba' kú, tani yó joyè (If Olúbàdàn dies, who will replace him).

With various works done on the Yorùbá subculture of drums, drumming, and the characters involved in its transmission from generation to generation from the days of Àyángalú, it is worthy to note the Àyàn family line. Ayyàn family line is the family that majors in the production of assorted kinds of Yorùbá drums. They kill animals, tend their skins, tanned it well and prepare the drum faces and tone variation leather strings.

History shows that the practices in this family are to prepare them for future drumming 
activities and make them bold before audience. They are to go and beg for water from next neighbour to feed their newly born child. By doing this, they belief doing it will make the young sharp as he grows to engage in drumming and collect money from people as he plays to eulogize them. Though, this act of Drums is an important aspect of the cultural heritage of the Yorùbá, especially the attendant impact on the generational transfer of this heritage territorially. Culture has not been proven scientifically today whether there is a correlation between begging for first water to give to their new baby and being shy or afraid to address audience of and size.

The Àyàn are known anywhere in Yorùbá land as drummers. Anyone that bears that name without introduction will be known to be from a drum family. By practice, as this young one grows up including the female ones, the parents prepare small drums for them with which they play along with them when they go for outings or ceremonies. This family, like media today, goes to war with fighters and is protected as they eulogise the fighters with tunes from their super drums. They also pass comments about the situation on the warfront using their drums. When the Àyàn daughters are given out in marriage, a specialized drum Dùǹún with Saworoide (small bells) is given as a parting gift. Drums ranges in size. It can be as tall as eleven (11) feet and it can be as small as putting it under one's armpit. The size of a drum doesn't determine the dignity attached to it. The size of a drum determines the sound it produces. Thus, every drum has its peculiarity in terms of the sounds(s) they produce.

\section{Types of Traditional Drums}

Traditional Drums of Yorùbáland are numerous. Examples include: gángan, dùǹdún, omele, àsíkò, shákárà, gúdúgúdú, bàtá, bẹ̀mbé, gbẹ̀du, àgbá, etc. Some are combined to form an ensemble. Thus, you have dùndún ensemble, bàtá ensemble, gbẹ̀du ensemble to mention few.

\section{Gángan}

Gánganis, a two face drum also known as "talking drum". Ológúnjọbí (2016) asserts that in the tradition of Yorùbá people, Gángan holds a special place. In Yorùbá, folklore cannot be set aside. Its origin can be traced back to The old Oyọ́ Empire in South-Western, Nigeria. During the coronation of the Aláàfin of Oyó, it was introduced as a means of communication. In the Yorùbá language, talking drums are used to imitate chant patterns and different tones. It is made of adjustable cords and also made in an hourglass shape, which makes it possible for it to be held under the arm. These cords are used by the drummers to determine the pitch of the drumbeat. The cords and springs has its functions, if they are pulled hard, the sound or tone from the drum would increase and if the cords are softly tighten, the sound will be low. They are used in festivals, wedding ceremonies, modern churches, and carnivals.

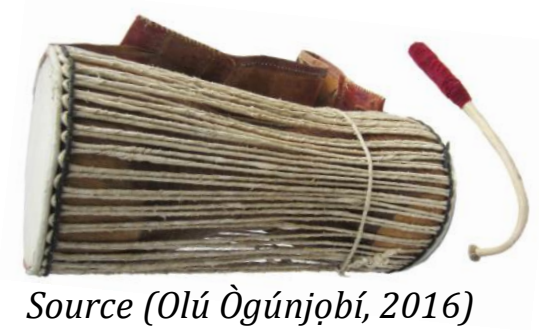

\section{İgbìn Drum}

Ìgbìn drum is a traditional drum affixed to the worship of Obàtálá. It is made with the dermis of İgalà (deer). According to Oládoṣù (2015), any deity that has a link with snail (called İgbín) is always worshipped using the İgbìn drum. Ėjìgbò people of Oyó state in Nigeria, use this İgbìn drum during the New Yam Festival to commemorate the celebration.

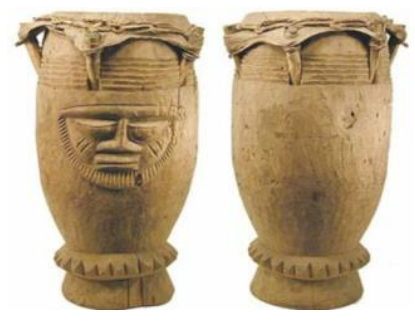

Source (pininterest.com) 


\section{Bàtá}

Bàtá is also an important drum used in Yorùbáland. It is a double-headed cone-liked shaped drum with one of the cones larger than the other. It is mainly associated with Șàngó. It is used to pass or carry messages of hope, divination, praise and war. A set of bàtá consists of three drums of distinct sizes. The bàtá are played sitting down with the drum laid horizontally on the knees, which makes the drummer play with both hands. The Iyá İlù ("Mother") has a detailed cycle with many technique and initiates conversations with the other two drums and it is the largest drum and leads the group playing.

İyá Ìlù has garland of bells and bronze caps which often beautifies the edges of the drum called "Saworo". It endows the vibrations and sounds made from the drum when the drummer plays the instrument detailed cycles with some techniques as well as a response and occasionally initiating conversations. The Ìtótèle is the middle-sized drum, playing long, but less. The smallest of the three playing short is the Òkóńkóló, which has simple cycles with occasional conversations and techniques. The bàtá drum has distinct parts which include; "Igiìlù" (wooden frame work), leather, "Egiìlù" (thick brooms for support), "Ọsán” (wire work), "Iro" (black substance placed on the drum surface), "Búlálà" (drumstick made from leather), and cowries.

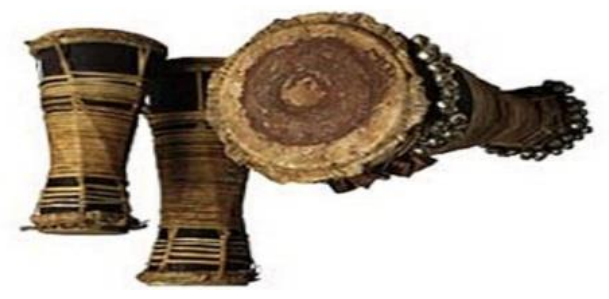

\section{Dùndún}

Dùndún is a cylindrical rope tuned drum with a raw hide skin at ends, most usually cow or goat. A plain straight stick, curved stick with flat head attached at right angles near one end can be played with the drum; depending on the angle which the stick touches and may be used to hit the skin i.e. the drum.

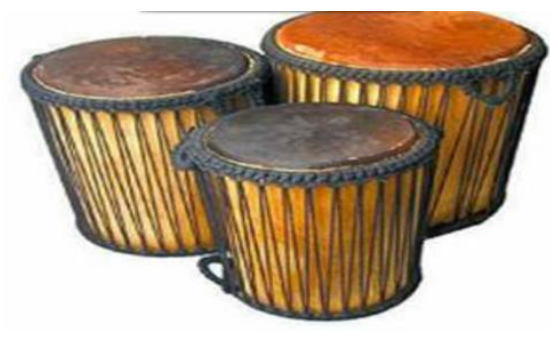

Source (yorupedia.com)

\section{Bè̀mbẹ.}

Bẹ̀mbẹ is played with hands rather than with sticks. It is common to be accompanied with two bells. It is the most recognized sacred drum used during Oșun and Oya Festivals.

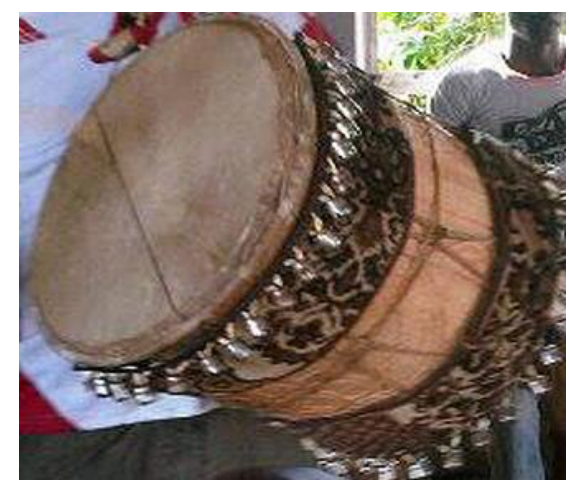

\section{Àshíkò}

Among the Yorùbá people, Àshíkò is another important musical instrument. Àshíkò is a cylindrical tapered formed drum with a wide head end and its down end narrowly opened. It's mainly created with hardwood and goatskin/ hide, tuned by ropes and being played with the hands. They are mostly used in festivals.

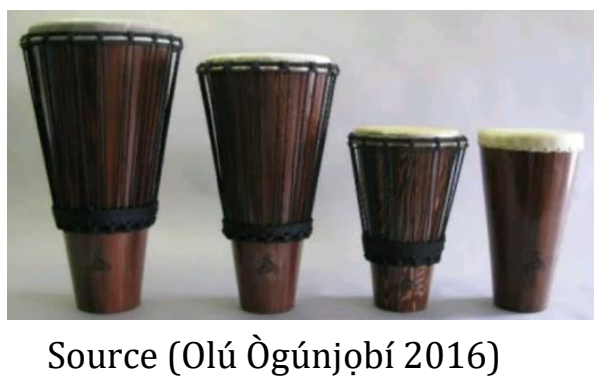


Journal of Language and Literature

ISSN: 1410-5691 (print); 2580-5070 (online)

\section{Importance of Traditional Drums}

Traditional drums play important roles in every appearance of human life and this range from spiritual to physical to emotional and to social. Traditional drums help to define the rich culture of Yorùbá. They are great custodians of the rich and beautiful Yorùbá heritage. They a used as means of communication; I used for sending messages from one town to another. Drums are used as healing therapy. Drums have spiritual powers that make it beyond natural; when beaten it moves into the nooks and crannies of a man which touches the body and awakens the soul. It holds a great symbolic and historical meaning. They are good accompaniment for any kind of ceremony such as birth, death, marriages, coronation set, and it goes along with a beautiful dance ritual. It graces and beautifies a ceremony. The vicious sound of these traditional drums stirs up feelings in a battle or war to behest the warriors at the war front to fight and be victorious.

\section{The Effect of Colonization on Traditional Drums}

As mentioned earlier, colonization plays an ambivalent role in the life of Africans. Colonization brought formal education into Africa. Formal education made people enlightened and these enlightenment was like an eye-opener for African especially Nigerians. Education brought new innovations and creativity. For example, in the traditional African setting drums were made from trees with animal hides and skin but today polythene materials made from in-organic petro-chemical product have now been adopted to make the strings and cover instead of animal skins. Metals and sewers are now used in tightening the face of the drum. The materials used in the production of these drums have made it possible to produce these drums in large quantity and has increased the accessibility of people to these drums, unlike in the pre-colonial days, when these drums were made only by a specific family especially the Àyán Agalú family; who are custodians of the drums.
Aladesanmi 0mobola Agnes

The bitter part of colonization supersedes the positive part in that colonization has robbed us of the dignity of our culture. Nowadays, the awesomeness and sacredness attached to our culture has been replaced with modernization which has blindfolded our youth to the beauty of our culture. In the pre-colonial days, drums cannot be made by just anyone interested in the making of a drum. There is always a rite undertaken before a drum can be made. Every drum in the olden days has a deity that is attached to it. It is the same respect accorded the deity that is accorded the drum which is used in worshipping it.

There are always seasons attached to each drum, one cannot just beat a drum without a reason and it should also be noted that not anyone can beat these drums. There are designated people who beat these drums; but civilization and modernization has exposed these drums such that they are now beaten anywhere, at any time and by anyone. For example, the Gángan drum is beaten in palaces; it has to do with the enthronement and coronation of kings. In the olden days, some powerful kings are woken from sleep using the gángan drums and the Șaworoide is often used for the enthronement of kings. There is a particular movie titled "Șaworoidẹ" by Mainframe Productions; the movie gave a clear explanation of the significance of the Saworoide drum. Furthermore, the rite involved in the burial of a drum is no longer observed. Nowadays, broken drums are discarded without observing the rites attached to it. Even sometimes broken piece of drums can be seen burnt in fire. This rite has been earlier mentioned in this paper.

In the pre-colonial days, Kings were lords and the custodian of our culture. Colonization submerged and dismantled the ever vibrant indigenous institutions and replaced it with the foreign rule and culture. The kings used to have chiefs who serve in different capacities to uphold the sanctity of our culture. For instance, these traditional drums are kept sometimes in sacred dwellings which are under the auspices of a particular chief but these days the chiefs are 
more of ceremonial titles and many of them do not even know or respect the rich culture of the land they represent.

Positively, colonization has really also helped in making drums a source of income because the drums that were used to be housed in sacred dwellings are now found in various places ranging from churches to social gatherings and even for entertainment. A particular musician in Nigeria called "Lágbájá" is so fond of entertaining his listeners with beautiful tunes using different kinds of traditional drums like the talking drums, dùndún, omele, bàtá, etc. It can be concluded that colonization has helped in commercializing our traditional drums.

\section{Conclusion}

Drums are mystic in nature. It has supernatural power backing it. No matter how hardened a person's heart might be when he hears drumbeats, his heart softens. When at warfront or in the heat of a fierce battle, if a drummer begins to eulogize the warriors, the head of the warrior will swell and this makes the warrior want to win the battle. As mentioned earlier, the drummers follow warriors to warfront.

Colonization introduced the "tàka n súfèe" (It is a type of dance common among the youths) in Yorùbá music. The musical instruments are replaced by western instruments, A Typical example is the keyboard. Colonization brought westernization. It is now being plagiarized or mimicked on organs. Most drums have now been synthetized electronically thereby reducing the physical importance and presentation of the original Yorùbá musical instruments like gángan, ìyáilù, omele, and other accompaniments. The voices of these drum are on organ. Gángan has its own dress code, presentation, the cultural display, and dancing steps which cannot be seen on organs. Women dancing, spraying of money, flowing of agbáda, hairstyle has been adulterated. The cultural values attached to the drum shave been jeopardized.
In conclusion, permit me to say that drums can be stolen, it can be duplicated; but it can never be killed. Colonization can only change the presentation of drums and resell it back to Yorùbáland, our drums are our heritage; we must fight with all that we have to keep our heritage.

\section{References}

Adépọ̀jù, Oti \& Oyèbọ́lá Ayẹni. (2013). "Yorùba Culture of Nigeria: Creating space for endangered specie". Cross cultural communication, 9(4), 23 - 29.

Adénlé, Tọ́la. (2014). "The Diaspora, the Drummer, and the Drum". Emotan's blog.

Adénlé, Tọ́lá. (2014). “Yorùbá Drums and Drummer". Emotan's blog.

Arówólò, Dáre. (2010). "The Effects of Western Civilisation and Culture on Africa". AfroAsian Journal of Social Sciencepp. 1.

Àjàyí, Bádé. (1985). “Aspects of the Yorùbá Talking Drums". Proceedings from the Fourth Annual Congress of the Nigerian Folklore Society held at the University, 494 $-515$.

Àjàyí, Bádé. (1992). The Cultural Semantic of Yorùbá Drums. "Chinese Semantic Studies", 10(3). $451-463$.

Àjàyí, Bádé. (1992). “The role of Yorùbá Talking Drum in a Social Mobilization". Research in Yorùbá Language and Literature, 3, 1 - 9.

Japhet, Alakam. (2017). "Excellence in Style: The Uniqueness of Yorùbá Drums". Vanguard, February 12.

Amponsah, S. (2010). "Beyond the Boundaries: Tóyìn Fálọla: The Man, The Mark, The 
Muse". North Carolina: Carolina Academic Press.

Bankole, A, et. al. (1975). "The Yorùbá Master Drummer". African Arts. UCLA, 53.

Falana T.C. (2018). "Philosophy as a Tool for Decolonization". World Scientific News: WSN 98, 23 - 33.

Hofstede, G. (1997). Cultures and organizations: software of the mind.

Igboin, 0. Benson. (2011). "Colonialism and African Cultural Values". Africa Journal of History and Culture, 3(6), 96 - 103.

James, J.A. (2015). “Talking drums: Delineating between the boundary of uses and Border of Abuses in South-Western Nigeria". New Media and Mass Communication, 44 - 49.

Kasongo, K. (n.d.). Impact of Globalisation on Traditional African Religion and Cultural Conflict, $309-322$.

Ọládoṣù, Olúșégun. (2015). "Yorùbá Indigenous Drums: An Aesthetic Symbol in Ecological Ritual of the Yorùbá People". European Scientific Journal, 11(5), 214 - 230

Olú, Ògúnjọbí. (2016). "Nigeria: 6 Important drums of the Yorùbá People". Nigerian Bulletin. 1-8.

Ushe, M.U. (2013). The Talking Drum "An Inquiry into the Reach of a Traditional Mode of Communication". Journal of Cultures Society and Development. 1, 94(1), $94-96$

Webster's Dictionary of English Language. (1995). New York: Lexican Publications 